\title{
Localities of Value: Ambiguous Access to Land and Water in Southeast Asia
}

\section{Laurens Bakker, Gerben Nooteboom and Rosanne Rutten}

In Southeast Asia, access to localities of value, such as forests, agricultural land and fishing grounds, is increasingly contested as economic and demographic growth puts an ever intense pressure on natural resources. Local populations compete among themselves and with outside actors (such as private companies, government bodies and environmental groups) over the use, control and protection of these valuable resources. The specific form that this competition takes reflects an ambiguity in resource control, shaped through a process of 'fuzzy logic'. In this special issue, we take Indonesia and the Philippines, two countries with recent histories of democratisation and decentralisation of state power, as telling examples.

We call these processes of resource access and control 'ambiguous' because claims and rights often overlap, and the processes are unpredictable and multifaceted. In many cases, no single actor has gained absolute control over valuable localities. Rather, multiple authorities are involved (the state, adat community leadership, private companies and NGOs) and these are often sufficiently independent and powerful to contest each other's validity, they may also turn into allies or competitors of local populations in shifting configurations of power. We see, moreover, a fuzzy logic at work: In many cases, access to valuable localities in Southeast Asia is neither fully legal, nor secure. ${ }^{1}$ Access always involves insecurities due to contested forms of legitimisation, the opportunity of employing multiple sources of legitimisation (including state law, international human rights and claims of ancestry), the absence of a single regulating authority (such as the state) and the relative nature of access (relative to other contenders). Access is, therefore, subject to continuous contestation, renegotiation, bargaining and accommodation through which all the parties

1 With thanks to Frans Hüsken who suggested the usefulness of the term 'fuzzy logic' for the processes described. 
involved may land up with some access and control. Fuzzy logic suggests that local actors cannot predict the outcome of such interactive processes; neither can academics, who are also constrained when endeavouring to make absolute statements on rights of access.

This special issue then highlights the social and political reality of resource control in Southeast Asia that is a result of ambiguity and fuzzy logic and should therefore be understood and studied in these terms. Our approach contrasts with those studies on resource competition in Southeast Asia that emphasise either the role of the state and structural social factors (such as power differences, socioeconomic inequalities and capitalist expansion) or local populations, resistance and people's agency. Instead, the contributors to this special issue adopt a more inclusive, multi-actor analysis that considers the dynamic interaction of all the relevant parties concerned.

The context of democratisation and decentralisation in the Philippines and in Indonesia is certainly relevant here. These processes have added to the multiplicity of actors in the local arenas where access to valuable localities are contested and negotiated. As authoritarian regimes have been replaced by more democratic governments, state authority has been delegated from top administrative levels and controlling elites to bureaucracies that extend to the village level. This widening democratic space has, in turn, enabled NGOs and social movements to establish a presence in village communities. Decentralisation and democratisation have thus empowered actors at the community level, including state actors, such as village and municipal councils, local offices of the state's line agencies and local-level government officials. For NGOs and local populations, government has become an up-close reality that contains potential allies, as well as providing opportunities to call local officials to account for state actions. These processes thus expand the range of potential allies for local populations and facilitate communities' access to new or revived arenas in which to stake and defend their claims.

Resources may be fought over in various social arenas, distinguished by the type of actors, their strategic interests and claims, and the grounds on which they legitimise these claims. These arenas include the arena of customary law and traditional community leadership, the arena of state law and government agencies, the arena of NGOs and social movements that appeal to human rights in various forms (the rights of indigenous peoples, peasants and plantation workers, for instance) and the arena of liberal market doctrine upheld by private enterprises and some state actors. Legitimising discourses and substantiating rights are essential to all the actors operating in these arenas. Local populations may try to establish valid resource claims by operating in multiple arenas, using multiple discourses on rights. Although this may take place through conflict, more often it involves ongoing negotiations. 
Discourses used to legitimise claims tend to refer to a shared notion of how things ought to be whereas, when claiming 'rights', people refer to more established rules and the interpretation of such rules. Fresh takes on rights require a new discourse that substantiates, as well as validates; however, such efforts are unlikely to succeed without forming coalitions or if discourses are not shared and recognised among various actors in the arena. The underlying logic is fuzzy because the validity of the various competing claims is relative, continually adjusted to changing power configurations and subjected to permanent renegotiation.

In this issue, Franz and Keebet von Benda-Beckmann discuss struggles over access to village commons in West Sumatra in the post-Suharto period. They use these cases to argue a broader point: That the ambiguity in the strategies used by various actors to claim access to the commons is shaped by the embeddedness of property rights in different domains of society (including the legal, social and authoritative spheres), and the complexity of plural legal orders which gives rise to legal insecurity. "In the process," the authors argue, the actors "create ambivalent and opportunistic ways to negotiate property relations and to justify their interpretations of actual conditions, claims and solutions in legal terms."

Bakker and Moniaga approach these embedded processes on a nationwide scale in looking at both conflicts and alliances in nine different land disputes across Indonesia. They investigate legal arenas and discern three basic constellations through which legitimisation is sought: (1) national state institutions; (2) regional autonomy opportunities; and (3) extra-legal arrangements. For local people, the lowest government levels offer the best chances of success but security and legitimisation are strengthened with an increase in the level of ratification. Forming broad alliances is an efficient strategy for gaining rights to land but these rights remain insecure, are often shared with other parties and remain potentially open to new claimants.

Rosanne Rutten discusses an unpredictable, pluriform process of resource access and control in a totally different setting. Plantation workers in a sugarcane-producing region of the Philippines compete among themselves to qualify as rightful beneficiaries of a government land reform programme. The form and outcome of these community-based struggles depend on the interactions of the workers with the different stakeholders involved (other plantation workers, plantation owners, state agencies, farm worker movements and NGOs). The author shows how workers' engaging in the different power arenas (the arenas of the state, market, social movements, landowner patronage and the plantation community itself) affects the validity of their claims.

Titia Schippers analyses how local leaders in a municipality in the Cordillera Highlands in the Philippines strategically used the state-sponsored 
'indigenous peoples rights' discourse and administrative structures to acquire land rights for the municipality's inhabitants. The case illustrates how claiming indigeneity can be a powerful tool in attempting to obtain collective land rights and to protect community territory from potential encroachments by outsiders, such as mining and logging companies. It shows that indigeneity is not a fixed given, but an identity that can be mobilised, and to an extent created, for claiming a stake on a specific territory. Neither the claim, nor the justifying discourse of indigenous peoples' rights were fully secured or accepted locally. Her contribution reminds us that a claim granted in one arena (an 'ancestral domain' granted at the state level) may still be contested and revoked in another arena (in this case, the municipal arena of electoral politics).

The final two articles, by Acciaioli and by Nooteboom and De Jong, provide contrasting cases involving environmental arenas. Both deal with fisheries, ecological concerns and resource control at freshwater lakes in Indonesia, and focus on the non-local frameworks and interventions that have set the parameters for resource use and the local exercise of agency in regard to the use and the valuation of resources. Whereas Acciaioli describes a highly successful case of sustainable resource use - at least from the local people's point of view - Nooteboom and De Jong stress the harsh reality in which local communities are often unsuccessful in managing resources. In the latter case, fuzzy logic and ambiguity in resource use are not to the advantage of local people. The authors ask why local fishing communities do not resist outside actors, and seek an explanation for why they are unable to protect and manage their environment in a sustainable way. Their article challenges those 'green development fantasies' and optimistic approaches that put their faith in the capacity of local communities to manage local resources. Moreover, the article shows that legal insecurity and ambiguity in access to localities of value is not, as is sometimes claimed, always beneficial to local people.

These six contributions suggest that for communities to obtain access to valuable localities it is crucial that they field discourses of rights that transcend those of their competitors. The contributions highlight several discourses at work:

1) Claims based on rights derived from state law. This discourse is most commonly used in relation to development and modernising projects by government bodies and companies; at times, it is also advanced by population groups and NGOs.

2) Claims based on special relationships or privileges to a resource, such as discourses on indigeneity and customary rights. 
3) Claims along broader and less specific lines; such as discourses based on livelihood needs, poverty alleviation or international human rights law.

Analysing resource conflicts along multiple discourse lines can assist researchers in determining a detailed typography of the limits of the state. The contributions put ostensibly simplistic dichotomies, such as power-holders and the powerless, or of indigenous and migrant identities, into perspective. They make clear that a more realistic research method, such as the arena approach, is needed to deal with the complex dynamism of discourses that attempt to validate access to localities of value.

Taken together, the contributions suggest that competition over access to land and fishing grounds may take place in alternating sequences of negotiation and open conflict. Without absolute authority, unequivocal juridical foundations or an irrefutable strategy, agreements may always break down and be reshaped through conflicts in one or more arenas until a new consensus is established. The process is thus one of continuous dynamism: Struggles over access to valuable localities are seldom settled once and for all.

We also discern a rise of local groups vis-à-vis structures of authority in these competitive processes, although we would emphasise that the poor and the disadvantaged do not necessarily stand to gain from this. Entrepreneurs and power brokers may appropriate local identities and engage in coalitions with authority holders to further their own agenda. The competition may thus weaken rather than strengthen the position of the disadvantaged.

The contributions show that access to localities of value in Indonesia and the Philippines is not always a democratic process governed by the rule of law, but neither should it be seen as monopolistic or totalitarian. The state is not an all-powerful entity; local government officials are often unable (and possibly unwilling) to fully control access to valuable localities and instead seek ambiguous solutions inspired by the pragmatics of fuzzy logic. The fragility of such approaches is, however, continually tested by the arrival of adventurous actors from outside and the emergence of new leaders from within. Lack of clear rules and the access to resources granted to those who are victorious in the various arenas, make access both insecure and dynamic. Although this provides opportunities to groups whose claims are not recognised by official law (see the contributions by Acciaioli and by Bakker and Moniaga in this special issue), the ambiguity in access to localities of value should not be celebrated. It remains to be seen whether the opportunities this offers to the weak are not at least equally accessible to those with power (see Nooteboom and De Jonge) and whether this ambiguity does not, in the end, work against the landless, the poor and the oppressed that seek to profit from its existence. 